Apart from the museum and aquarium, the institute has three chief departments-biology, physics and chemistry and geology and geophysics. It also houses the IAEA Laboratory of Marine Radioactivity and the institute's research vessels are at everybody's disposal. Naturally, the institute is principally concerned with the Mediterranean and with physical rather than biological oceanography, but the biologists are surveying the populations of organisms on the continental shelves off Corsica and Tunisia. In collaboration with the Department of Physics and Chemistry, they are using continuous recording apparatus to measure $p \mathrm{H}$, salinity, temperature and oxygen tension and to correlate these parameters with marine populations. There is also a project for recovering bathypelagic animals and maintaining them under the appropriate pressure and temperature for study in the laboratory.

The institute as a whole has a particular interest in radioactivity in the sea and, in conjunction with the IAEA laboratory and a Laboratory of Radioactivity financed by the Centre Scientifique de Monaco (which also provides one of the three carbon-14 dating services in France), the biologists are studying the metabolism of radioactive iodine, iron and chromium in seawater by marine animals. This work is closely related to that of the IAEA laboratory, which in the past has been solely concerned with the fate of radioactive materials disposed at sea. Extraordinarily little is known, however, about the consequences of marine radioactive pollution and there has been much argument about the practice of dumping in the sea. One way and another, however, it seems that the most forceful arguments against this method of disposal have been softened lately, but critics of the IAEA laboratory, who see little point in competing with national laboratories in this field, have had their way. In future, the IAEA laboratory at Monaco will spend most of its time trying to standardize methods for measuring marine radioactive pollution. One of the obstacles to international agreement is the diversity of measuring techniques in use.

The Physics and Chemistry Department at the institute is developing apparatus for continuously recording parameters such as salinity and $p \mathbf{H}$, and there is also an ambitious project for measuring by neutron activation analysis ten trace elements in seawater in collaboration with the Centre d'Etudes Nucleaires at Grenoble. In collaboration with workers at Marseilles, the group is also working on gas chromatographic analysis of dissolved gases. The geophysicists developing and using seismic reflexion techniques have, during a survey of the sea floor between France and Corsica, recently discovered salt domes piercing fracture lines in the seabed similar to those in the Gulf of Mexico, and there is cheerful talk about the possibility that oil may be associated with these structures.

\section{NATIONAL ACADEMY}

\section{New Job for Shannon}

Dr James A. Shannon, who retired as director of the National Institutes of Health at Bethesda on September 1, has been appointed special adviser to the President of the National Academy of Sciences. Dr Shannon will advise the president and the council on academy programmes and activities, which involve medicine, biology and other sciences related to problems of human health and wellbeing. Among these programmes are the Board on Medicine, a group recently established to study the social functions of medicine; and the numerous committees which are concerned with controversial topies such as tissue transplantation, drug dependence and the biological effects of atomic radiation.

Dr Shannon has had a distinguished career in both medical research and in the US Public Health Service. During World War II, his work on malaria research and as consultant on tropical diseases won him the Presidential Medal for Merit, at that time the highest award for civilian service to government. Since then, Dr Shannon has gained several awards, among them the Rockefeller Public Service Award for the "sustained excellence of his service to the nation's scientific effort", and in 1966 the Presidential Distinguished Federal Civilian Service Award.

\section{EUROPEAN ACADEMICS}

\section{British-ltalian Collaboration}

As part of the general move to promote closer links between scientists in Europe, the Royal Society and the Accademia Nazionale dei Lincei of Rome are engaged in discussions. At the invitation of the Lincei Academy, the president and other representatives of the Royal Society went to Rome for a discussion with Italian colleagues in January 1968. It was decided then to appoint a joint committee to consider possible ways of increasing scientific cooperation between the two bodies which might be of scientific and economic benefit to both Italy and the United Kingdom. The first meeting of the joint committee was held at the Royal Society on May 16, 1968, when Professors A. M. Angelini, G. Puppi and G. Sartori met Sir Harold Thompson, Professor B. H. Flowers, Professor H. Ford, Sir Ashley Miles, Professor J. Z. Young and other representatives of the Royal Society. Unfortunately two other Italian members of the committee (Professors R. Margaria and G. Montalenti) were prevented at the last minute from attending. The present level of exchange between Italy and the UK in the Royal Society European Programme was reviewed, and it was agreed that, in spite of recent increases, there was still some room for expansion, especially in fellowships from the UK and Ttaly. Efforts are being made to make the active centres of research in Italy better known in the UK.

One important innovation is that the discussions have led to the suggestion that British and Italian scientists who have good plans for collaborative projects should submit their grant applications simultaneously to the Science Research Council and the Consiglio Nazionale delle Ricerche respectively. Although it seems to have been recognized that discussion between British and Italian scientists would be of value in many fields, a few subjects have been singled out for encouragement. These included astronomy, biomedical engineering, computer software and polymer engineering. It was also suggested that steps should be taken on a European scale to study the needs of scientific research in both physical and biological sciences for good electronic equipment. 